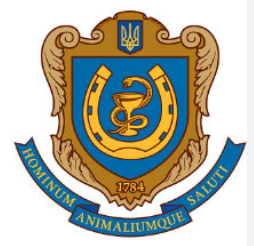

Ukrainian Journal of

Veterinary and Agricultural Sciences

http://ujvas.com.ua

Stepan Gzhytskyi National University of Veterinary Medicine and Biotechnologies Lviv

original article $\mid$ UDC 639.3.043:639.371.52 | doi: 10.32718/ujvas4-2.06

Volume 4

Number 2

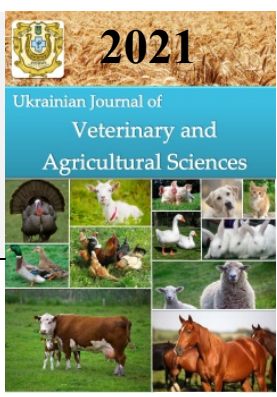

\title{
Intestinal histostructure and immune protection activity of age $-1+$ carp after consumption of a prebiotic feed additive
}

\author{
O. P. Dobrianska ${ }^{1}$, M. I. Zhyla ${ }^{2}$, O. I. Vishchur ${ }^{3}$, O. V. Deren ${ }^{4}$, M. Z. Koryliak ${ }^{4}$ \\ ${ }^{1}$ Lviv Experimental Station of the Institute of Fisheries NAAS, Lvivska Str., 11, Velykyi Liubin, 81555, Ukraine \\ ${ }^{2}$ State Scientific-Research Control Institute of Veterinary Medicinal Products and Feed Additives, Donets'ka Str., 11, Lviv, \\ 79019, Ukraine \\ ${ }^{3}$ Institute of Animal Biology NAAS, V. Stusa Str., 38, Lviv, 79034, Ukraine \\ ${ }^{4}$ Institute of Fisheries NAAS, Obukhivska Str., 135, Kyiv, 03164, Ukraine
}

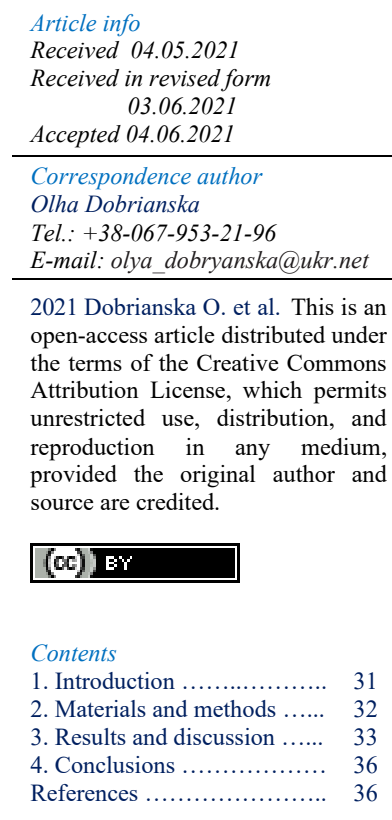

\begin{abstract}
Currently, it is important in aquaculture to study and use products and additives, which have positive effects on the digestibility of nutrients by helping to normalize the intestinal microflora, thereby modulating fish immune response. The aim of the study was to assess the effect of a prebiotic based on mannan oligosaccharides produced from the outer walls of Saccharomyces cerevisiae cells on the histological structure, morphometric state of the intestine and activity of cellular and humoral components of nonspecific resistance of age $-2+$ carp. The experiment was conducted in four analogous ponds, which were stocked with age-1 scaly carp with an average weight of 55-58 g with a stocking density of 1000 fish/ha. Carp had been fed balanced compound feed for 60 days. Experimental groups of fish were fed with a prebiotic as a feed additive in the amount of: $0.025 \%-$ Experiment 1 , $0.05 \%$ - Experiment 2 and $0.075 \%$ - Experiment 3. Use of the studied prebiotic did not damage the intestinal histological structure of carp of the experimental groups. The villi height and intestinal crypt depth of carp in Experiment $1(\mathrm{P}<0.05)$ and Experiment $2(\mathrm{P}<0.01)$ were larger compared to the control group. Experiment 3 showed destructive changes in intestinal mucosa. The results of histological examination indicated the effectiveness of the use of the studied prebiotic in the amount of 0.025 and $0.05 \%$ in the diet of age $-1+$ carp due to the absence of pathological changes and active morphofunctional state of the intestine, which, in turn, had a positive effect on feed absorption and metabolic processes in fish body. Analysis of the indicators of cellular and humoral links of natural resistance showed that in carp of the second and third experimental groups lysozyme activity of serum was 5 and $11 \%(\mathrm{P}<0.001)$ higher than in the control group. Similar changes, though found in a greater extent, were recorded in the study of bactericidal activity of blood serum, especially in individuals of the second and third experimental groups (by $6.8(\mathrm{P}<0.01)$ and $15.2 \%)$. While with carps of the third experimental group, which used a prebiotic drug in the amount of $0.075 \%$, the content of CEC was $20.5 \%$ higher than in the control group, which indicates an additional antigenic load on the body and is an unfavorable diagnostic factor. At the same time, with the fish of the second experimental group, which received, respectively, $0.05 \%$ of the supplement of the drug "Actigen" to the main diet, probably higher phagocytic activity of blood neutrophils was recorded. A direct dependence of the growth of the phagocytic index and the phagocytic number of neutrophils on the dose of the studied prebiotic was detected. Immunological studies indicated a dose-dependent effect of the prebiotic on the activity of cellular and humoral components of non-specific resistance of carp. Given this, for the effective functioning of innate protective mechanisms, for the increase of the body's immune potential and productivity, it is most appropriate to apply to the diet of carp prebiotic supplement "Actigen" in the amount of 0.025 and $0.05 \%$.
\end{abstract}

Key words: carp, prebiotics, mannan oligosaccharides, morphology, morphometry, intestine, resistance.

\section{Citation:}

Dobrianska, O. P., Zhyla, M. I., Vishchur, O. I., Deren, O. V., \& Koryliak, M. Z. (2021). Intestinal histostructure and immune protection activity of age-1+ carp after consumption of a prebiotic feed additive. Ukrainian Journal of Veterinary and Agricultural Sciences, 4(2), 3137.

\section{Introduction}

Aquaculture has been actively developing in recent decades leading to intensification of production according to the growth of consumer demand (Robb \& Crampton, 2013; Reverter et al., 2014). In the context of intensification measures in aquaculture, the main problems are an increase in fish morbidity and deterioration of ecological conditions of fish breeding environment, which leads to large economic losses (Bondad-Reantaso et al., 2005). Ichthyopathological situation can be controlled using synthetic chemicals and antibiotics that adversely affect the quality and consumer characteristics of fish products (Das et al., 2017). Given negative consequences of the use of antibiotics for preventive and therapeutic purposes in fish farming, alternative means are feed additives with immunostimulatory properties. 
Moreover, it is known that the quality of fish products depends primarily on the physiological state of fish organism, in particular on the functional state of the digestive system (Nayak, 2010; Ringo et al., 2010). Since the main source of energy in the composition of artificial feed in the cultivation of carp to marketable size are plant components, which are difficult to digest (Dekhtiarov et al., 2008), it is relevant and appropriate to find feed additives that would improve nutrient digestibility and normalize fish intestinal microflora by stimulating cellular and humoral mechanisms of protection (Song et al., 2014).

In this context, prebiotics, probiotics and synbiotics are environmentally friendly feed components for improving fish health (Hoseinifar et al., 2015; Akhter et al., 2015). In particular, prebiotics, which have a positive effect on fish body by suppressing opportunistic pathogens, are widely used in aquaculture (Ringo et al., 2010; Tarasenko \& Filippova, 2014).

Promising are prebiotics based on mannan oligosaccharides (MOS), the use of which promotes the development of a healthy surface of intestinal villi, which is necessary for better absorption of nutrients. This, in turn, improves the gastrointestinal tract integrity, effectively supports the immune system, and increases fish productivity (Ziółkowska et al., 2020).

In our studies, we used the prebiotic preparation Actigen (Alltech, USA), a highly purified, concentrated, specific controlled fraction of carbohydrates - mannan oligosaccharides, which is produced from the outer walls of yeast cells of Saccharomyces cerevisiae. The main effect of this product is to prevent colonization of the intestine by pathogenic bacteria by attaching pathogens to receptors on its surface, thereby blocking their ability to move and reproduce (Chernikova \& Procopenko, 2017). According to the spectrum of action of MOS, Actigen is able to normalize the production of mucin, which promotes the development of a healthy surface of the intestinal villi, which necessary for better nutrient absorption (Merrifield \& Ringo, 2014).

Among the most common prebiotics, mannan oligosaccharides are most commonly used as feed additives for various fishes and crustaceans (Sang \& Fotedar, 2010; Ibrahem et al., 2010). Numerous studies showed that these prebiotics improved growth parameters, survival, hematological and biochemical parameters, morphology and intestinal microbiota in seabass (Dicentrarchus labrax) (Torrecillas et al., 2007), rainbow trout (Oncorhynchus mykiss) (Dimitroglou et al., 2009), Atlantic salmon (Salmo salar) (GrisdaleHelland et al., 2008); Nile tilapia (Oreochromis niloticus) (Samrongpan et al., 2008), rohu (Labeo rohita) (Andrews et al., 2009), sea bream (Sparus aurata) (Gultepe et al., 2011) and Japanese flounder (Paralichthys olivaceus) (Ye et al., 2011).

Histological analysis of the intestine is a major factor in the complete assessment of the effectiveness of the use of prebiotics in fish feeding (Guerreiro et al., 2018). Some researchers reported changes (number, length, width, etc.) of intestinal villi and microvilli (Asaduzzaman et al., 2018), the number of mucus-producing cells, leukocyte infiltration (Guerreiro et al., 2018; Torrecillas et al., 2014). By stimulating mucus production, prebiotics enhance the bactericidal and lysozyme activity of blood serum (Torrecillas et al., 2011).

Our previous field studies found that the average weight of age $-1+$ carp fed with $0.025,0.05$ and $0.075 \%$ of the studied prebiotic was $6.3,21.3$ and $1.3 \%$, respectively, higher than in Control; fish productivity was higher by 10.0 ; 31.0 and $1.2 \%$; survival rate was higher by $2.4 ; 4.8$ and $1.2 \%$ (Dobrianska et al., 2019).

Given this, the purpose of the study was to determine the effect of supplements to the diet of carp of different amounts of prebiotic drug on the histological structure of the intestine and the activity of innate factors of protection.

\section{Materials and methods}

The study was conducted in 2018 at the fish farm “Karpats'kyi Vodograi” LLC, Pustomyty district of Lviv region, in four analogue ponds with a common source of water supply, which were stocked with age-1 scaly carp with an average weight of 55-58 g with a stocking density of $1000 \mathrm{fish} / \mathrm{ha}$. Fish were fed within the experiment for 60 days. The control group of fish received a balanced combined feed, while the feed of fish of experimental groups was supplemented by granulation with the studied prebiotic in the amount of $0.025 \%$ (Experiment 1), $0.05 \%$ (Experiment 2) and $0.075 \%$ (Experiment 3 ).

Animal experiments were conducted in accordance with the rules adopted by the European Convention for the Protection of Vertebrate Animals Used for Experimental and Other Scientific Purposes (European Convention, 1986).

At the end of the experiment, fish were caught and a complete autopsy of five individuals from each experimental group was performed.

The intestine of age -1+ carp were collected for histological and morphometric studies (Rotkiewicz, 1990; Zhyla, 2011). Pieces of the small intestine were preserved in a $10 \%$ neutral formalin solution, followed by dehydration in ethyl alcohol of ascending concentrations (70;80 and 96 $)$ and subsequent paraffin embedding. Histological sections of 7-8 $\mu \mathrm{m}$ thickness were made on a sledge microtome MS-2. Histological sections were stained with hematoxylin and eosin (Kotsiumbas et al., 2014). Generally accepted methodological approaches were used for morphometric studies (Avtandilov, 1996; Horalskyi, 2005). Microscopy was performed using an OLIMPUS CX-41 microscope, DP-SOFT morphometric software and an OLIMPUS C-5050 camera.

The material for immunological tests was blood collected directly from fish heart. Blood granulocyte phagocytosis was assessed by phagocytic activity (PA), phagocytic number (PN) and phagocytic index (PI). Serum lysozyme activity (SLA) was determined by the reaction to the microbial test culture of Micrococcus lysodeikticus (strain VKM-109) - a photonephelometric method. Aeromonas hydrophila was used as a test microbe for the determination of bactericidal activity (BASK) (strain 3605). These methods were carried out taking into account the specifics of experiments on aquatic organisms, using appropriate daily cultures of laboratory strains and cultivation temperature (Mikryakov, 1991). The content of circulating immune complexes (CIC) was determined by polyethylene glycol precipitation (Chernushenko \& Kogosova, 1981).

The obtained results were processed statistically by graphic and analytical methods using MS Excel XP and Statistica 10. Following standard statistical parameters were calculated: arithmetic mean (M), its standard error (m). Arithmetic means were compared using a Student's t-test. The difference the arithmetic means of the experimental and control groups was considered statistically significant if 
$\mathrm{P}<0.05$, which is a common approach in laboratory studies (Statistical principles, 2010).

\section{Results and discussion}

Histological examination of age $-1+$ carp intestine showed that its microscopic structure was preserved in all experimental groups. The intestinal wall was represented by three layers: mucous, muscular, and serous.


Experiment 3
The proper plate of the mucous membrane forms a protrusion in the form of villi and niche-like depressions crypts. The villi in fish of both experimental and control groups were well expressed. The villi of fish fed with a feed supplemented with the prebiotic in different amount were mostly of the same height, compactly located next to each other, covered with a single layer of cylindrical epithelium. Columnar epitheliocytes, goblet, and endocrine cells were found in the structure of the epithelial cover (Fig. 1).
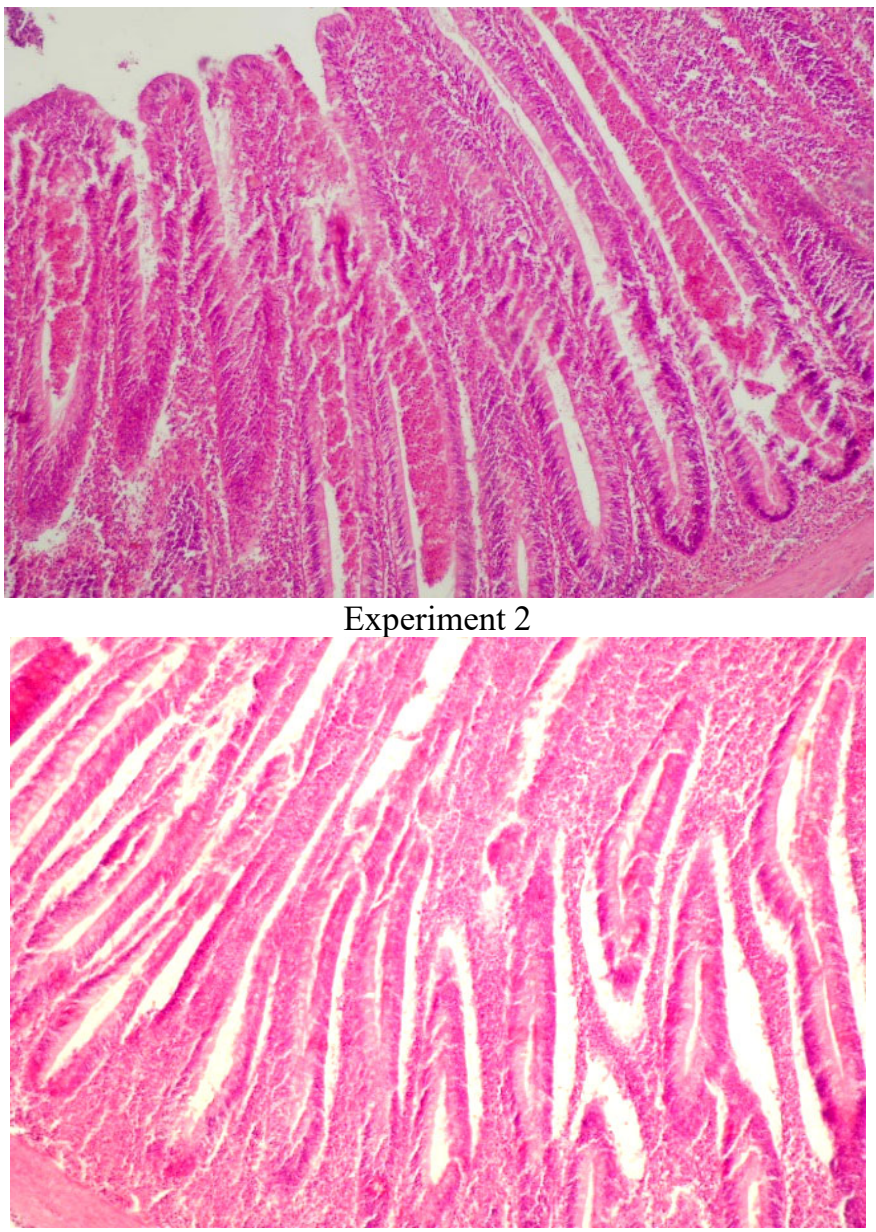

Control

Fig. 1. Histological structure of the intestine of age $-1+$ carp of experimental groups. H\&E. x 100

Columnar epitheliocytes of cylindrical shape, oval nuclei, in most cells were located in the basal part of the cytoplasm. Microvilli forming a brush border were well expressed on the apical surface of epitheliocytes. Goblet cells filled with mucus were found among the epitheliocytes. Crypts were represented by a tubular deepening of the epithelium into the proper plate of the intestinal mucosa. Entrance to the crypt was limited to the villi base. The crypt wall was built of columnar epitheliocytes and endocrine cells. The submucosal layer was represented by loose fibrous connective tissue with moderately filled blood vessels. A focal accumulation of lymphoid cells was also observed.

Histological study of the small intestine of carp of Experiment 3 showed destructive changes in the mucosa, including a larger number of goblet cells with mucus and their vacuolation, cellular infiltration of the submucosal layer, and thickening of the muscle layer compared with the carp of Experiment 2, which indicated mucosal hypersecretion (Fig. 2-5). Figures 6-9 illustrate intestinal crypts and villi of experimental groups of carp.

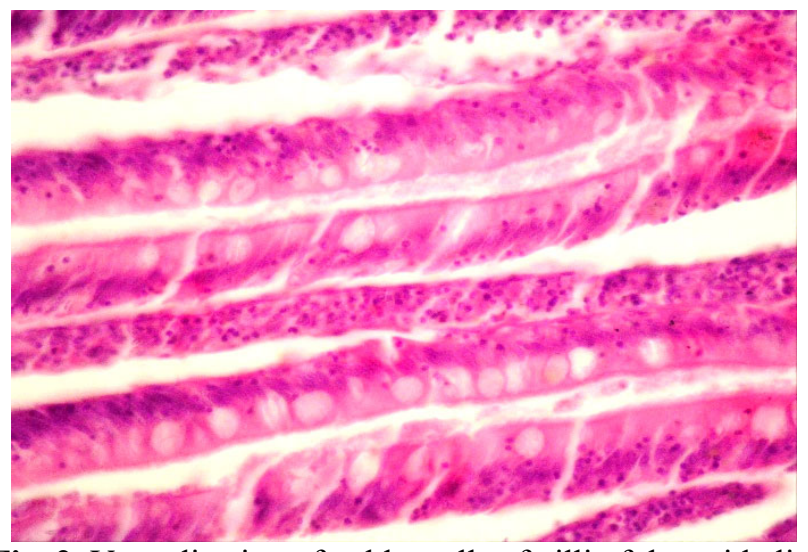

Fig. 2. Vacuolization of goblet cells of villi of the epithelial lining of carp intestine in Experiment 3. H\&E. x 400 


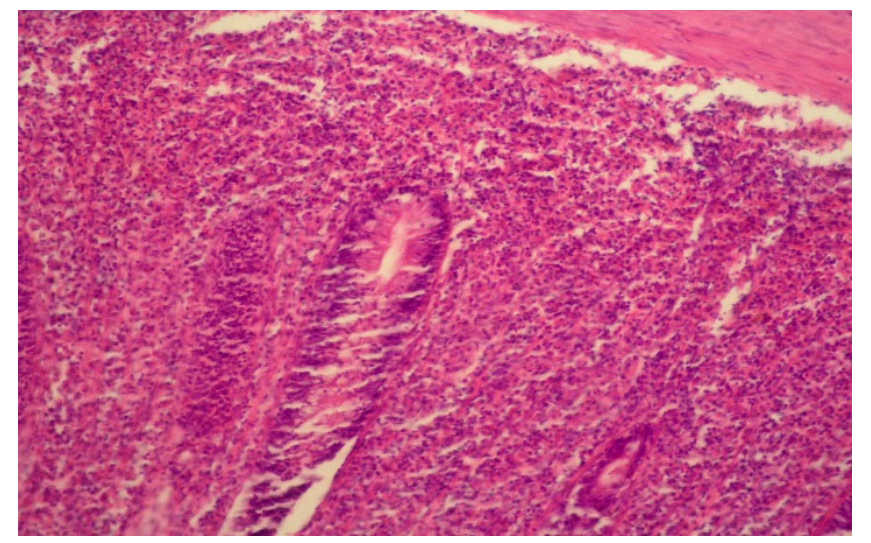

Fig. 3. Cellular infiltration of carp intestinal mucosa in Experiment 3. H\&E. x 200

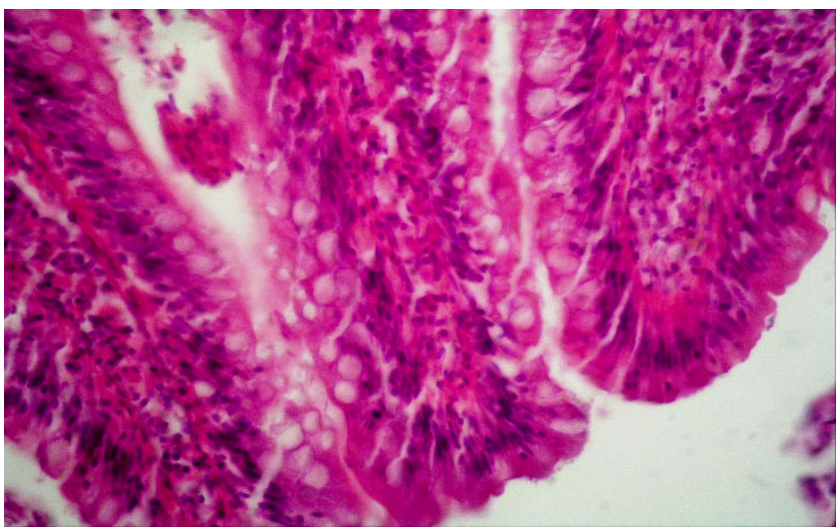

Fig. 4. Intestinal villi of carp in Experiment 3 with a significant number of goblet cells, hemocapillary dilatation. H\&E. x 400

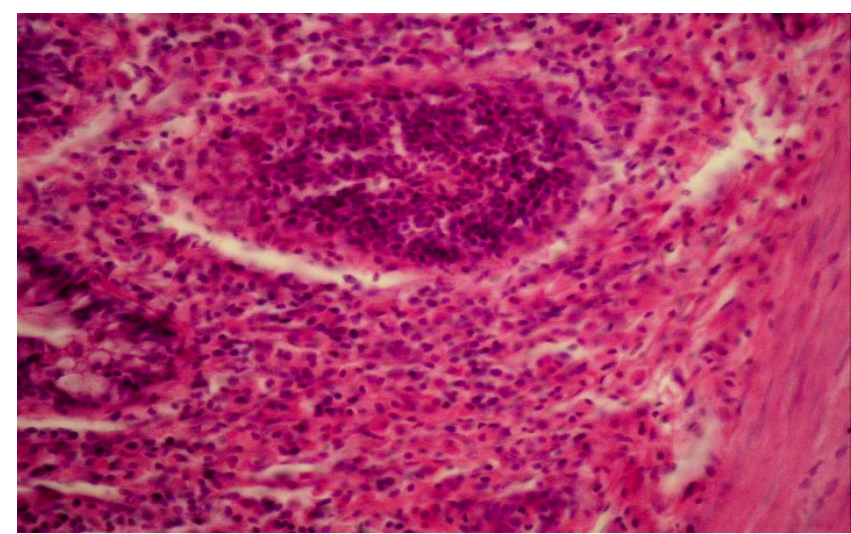

Fig. 5. Lymphoid nodule in the submucosal layer of carp intestine in Experiment 3. H\&E. x 200

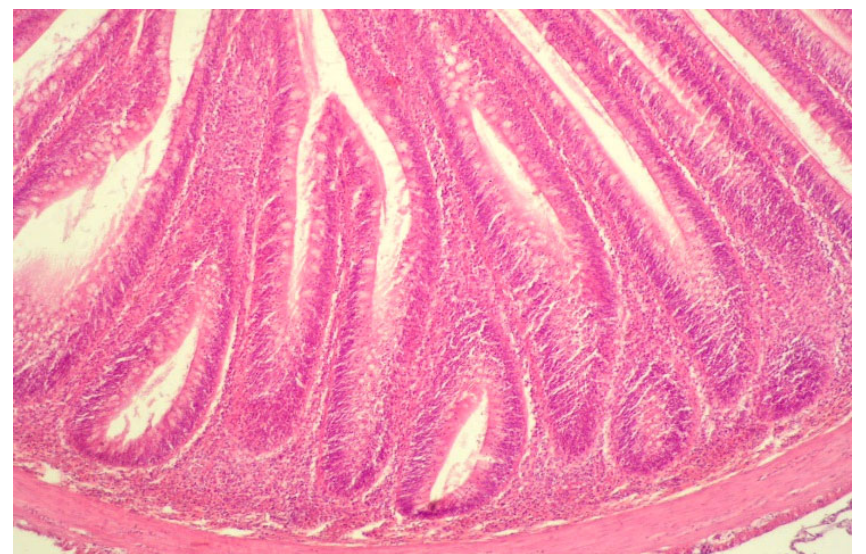

Fig. 6. Crypts of carp intestinal mucosa in Experiment 2. H\&E. x 100

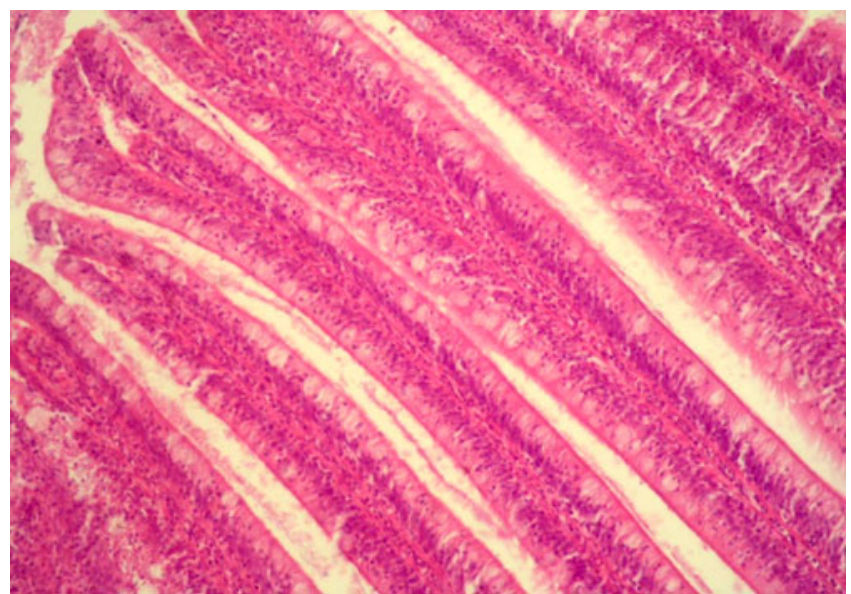

Fig. 7. Carp intestinal villi of Experiment 1 are clearly contoured and compactly placed. H\&E. x 200

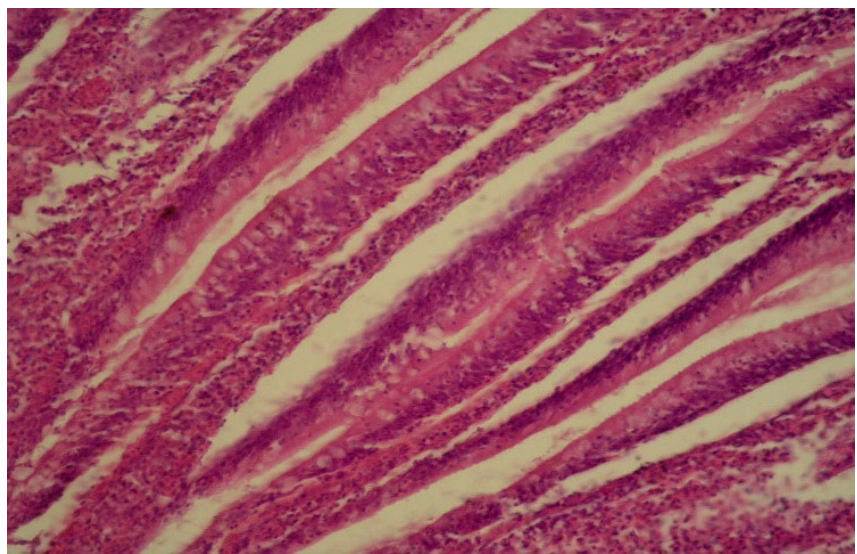

Fig. 8. Destructive changes of villi of carp intestinal mucosa in Control. H\&E. x 200



Fig. 9. Thickening of the submucosal and muscular layer of the intestine with focal cell infiltration and crypt elongation in Experiment 3. H\&E. x 200

A more pronounced difference in the morphological structure of carp intestine in the experimental and control groups was observed in the morphometric study, which determined the villi height, crypt depth and villi height to crypt depth ratio (Table 1).

According to the table, the height of the intestinal villi of carp of the experimental groups was higher compared to Control. Thus, the height of the intestinal villi of carp in Experiment 1 was higher by $52.6 \mu \mathrm{m}(\mathrm{P}<0.05)$, Experiment 2 - by $92.5 \mu \mathrm{m}(\mathrm{P}<0.01)$ compared to Control. As for carp of Experiment 3, this value was insignificantly different from Control. 
The most significant difference in the depth of intestinal crypts was also in Experiments 1 and 2. Thus, compared to Control, the crypt depth was greater in carp of Experiment 1 by $10.1 \mu \mathrm{m}(\mathrm{P}<0.05)$, Experiment 2 - by $33.2 \mu \mathrm{m}(\mathrm{P}<0.01)$. As for Experiment 3, this value tended to decrease compared to Control.

The villi height to crypt depth ratio in fish intestines was: Experiment 1 - 1:0.16; Experiments 2 - 1:0.19; Experiments 3 - 1:0.14; Controls - 1:0.15.
Increasing the villi height and intestinal crypt depth of carp of experimental groups in comparison with the control was positive, because it was related to an increase in the absorption surface of the intestinal mucosa, which, in turn, improved feed absorption and metabolism in fish (Koryliak, 2015).

\section{Table 1}

Morphometric parameters of the intestinal mucosa of age $-1+$ carp fed with the prebiotic additive $(M \pm m, n=4)$

\begin{tabular}{lcccc}
\hline \multirow{2}{*}{ Studied parameters } & \multicolumn{3}{c}{ Group of fish } \\
\cline { 2 - 5 } & Experiment 1 & Experiment 2 & Experiment 3 & Control \\
\hline Villi height, $\mu \mathrm{m}$ & $412.1 \pm 14.3^{*}$ & $452.2 \pm 18.3^{* *}$ & $361.8 \pm 33.4$ & $359.5 \pm 16.5$ \\
Crypt depth, $\mu \mathrm{m}$ & $65.0 \pm 3.1^{*}$ & $88.1 \pm 5.8^{* *}$ & $50.2 \pm 9.1$ & $54.9 \pm 3.4$ \\
Villi height to crypt depth ratio, units & $1: 0.16$ & $1: 0.19$ & $1: 0.14$ & $1: 0.15$ \\
\hline
\end{tabular}

Note: * $\mathrm{P}<0.05 ; * * \mathrm{P}<0.01$ compared to Control

Natural resistance of fish is an innate ability of its body to resist the harmful effects of pathogenic factors of biotic and abiotic nature, including pathogens of infectious and invasive diseases as well as products of their vital activity (exo- and endotoxins). Serum lysozyme and bactericidal activity, phagocytic activity of neutrophils are informative indicators of the level of adaptation mechanisms (Maslianko, 1999).

Feeding age $-1+$ carp during the growing season with a feed supplemented with the prebiotic caused a versified effect on the studied indicators of cellular and humoral components of fish natural resistance (Table 2).

Table 2

Parameters of nonspecific resistance of age- $1+$ carp under the effect of the prebiotic additive $(M \pm m, n=5)$

\begin{tabular}{|c|c|c|c|c|}
\hline \multirow{2}{*}{ Studied parameters } & \multicolumn{4}{|c|}{ Group of fish } \\
\hline & Control & Experiment 1 & Experiment 2 & Experiment 3 \\
\hline SLA, $\%$ & $29.8 \pm 0.66$ & $30.2 \pm 0.66$ & $34.8 \pm 0.97^{* * *}$ & $40.8 \pm 0.58^{\cdots \cdots}$ \\
\hline BASK, \% & $42.9 \pm 3.05$ & $45.5 \pm 4.69$ & $49.7 \pm 3.05^{* *}$ & $58.1 \pm 7.90$ \\
\hline $\mathrm{CIC}, \mathrm{mmol} / \mathrm{L}$ & $4.15 \pm 0.101$ & $4.32 \pm 0.124$ & $4.10 \pm 0.130$ & $5.00 \pm 0.114^{* \cdots}$ \\
\hline PA, $\%$ & $36.0 \pm 0.71$ & $33.8 \pm 0.58^{\circ}$ & $36.0 \pm 0.71^{* * *}$ & $34.8 \pm 0.58$ \\
\hline PI, units & $6.79 \pm 0.50$ & $7.44 \pm 0.61$ & $7.43 \pm 0.58$ & $8.65 \pm 0.14^{\circ}$ \\
\hline PN, units & $2.44 \pm 0.17$ & $2.23 \pm 0.14$ & $2.51 \pm 0.17$ & $3.01 \pm 0.01^{\circ *}$ \\
\hline
\end{tabular}

From the data in Table 2 we observe that the feeding of age $-1+$ carp during the growing season in the compound feed of the prebiotic drug "Actigen" causes an activating effect on the studied indicators of cellular and humoral components of the body's natural resistance. Thus, in carp of the second and third experimental groups, the lysozyme activity of serum was 5 and $11 \%(\mathrm{P}<0.001)$ higher, respectively, than in the control group. Similar changes, only marked to a greater extent, were recorded in the study of bactericidal activity of blood serum, especially in individuals of the second and third experimental groups 6.8 $(\mathrm{P}<0.01)$ and $15.2 \%$. The increase in the dose of the study drug in the diet of fish caused an increase in lysozyme and bactericidal activity of serum. These data indicate a dosedependent stimulatory effect of the studied prebiotic drug on the humoral parameters of the natural resistance of fish.

Circulating immune complexes are known to be an integral indicator of antigenic load on the immune system and their formation is a necessary component of a normal immune response (Haievska, 2000). Studies have shown that the content of circulating immune complexes in the blood of carp of the first and second experimental groups was at the control level, which indicates the absence of antigenic load on the body. However, in carp of the third experimental group, which were fed prebiotic drug in the amount of $0.075 \%$, the content of CEC was $20.5 \%$ higher than in individuals of the control group, which indicates the antigenic load on the body.

In the study of phagocytosis, which characterizes the cellular component of nonspecific resistance of the organism (Secomber, 1996), attention is drawn to the probably higher phagocytic activity of blood neutrophils in fish of the second experimental group with $0.05 \%$ of the supplement "Actigen" to the main diet. At the same time the direct dependence of phagocytic number and index of neutrophils of blood on a dose of the studied prebiotic preparation is stated. This is evidenced by higher phagocytic counts and phagocytic index in individuals of the experimental groups compared to the values in the fish of the control group. While with the carp that received $0.075 \%$ prebiotic to the main diet, differences in control were likely.

Therefore, the results of the studies indicate a dosedependent effect of the studied prebiotic drug on the activity of cellular and humoral units of nonspecific resistance of carp. Lysozyme and bactericidal activity of blood serum and phagocytic activity of blood neutrophils are informative 
indicators of the level of adaptation mechanisms. The increase of their level with fish of the experimental groups is an evidence of mobilization under the action of the studied drug of natural resistance factors, which may be due to the stimulating effect of the drug on intestinal mucus and cell activity of monocytic-macrophage system. The increase in BASK in carp may also be due to the effect of the components of the drug on B-lymphocytes and Ig, which have an opsonizing effect on bacteria, bind and activate complement, promote the induction of IFN and lysozyme synthesis. However, it should be noted that the formation of circulating immune complexes is one of the stages of the effector immune response aimed at removing antigens from the body. The detected increase in their level in the serum of carp of the third experimental group may indicate antigenic load on the body. It is known that prolonged circulation in the body can lead to organ pathology. When elimination is delayed, excess CECs negatively affect the course of immune processes, cause disturbances in the coagulation system, and activate the production of inflammatory mediators.

Given this, for the effective functioning of the natural mechanisms of protection and increase of the body's immune potential, it is most expedient to apply the prebiotic supplement "Actigen" in the amount of 0.025 and $0.05 \%$ to the diet of carp.

\section{Conclusions}

The macroscopic and microscopic structure of the intestine of age $-1+$ carp was preserved in all groups. It was found that supplementation of the main diet with a prebiotic additive based on mannan oligosaccharides in the amount of $0.05 \%$ had the most positive effect on the morphological state of the intestine of age -1+ carp and was characterized by functionally active epithelial cover, increased absorption surface of the intestinal mucosa. While the highest studied amount of the product in the diet $(0.075 \%)$ caused increased mucus secretion and polymorphocellular infiltration in the intestinal mucosa of carp, which indicated destructive processes in this organ.

A dose-dependent effect of the studied prebiotic on the activity of the cellular and humoral components of the nonspecific resistance of carp was observed. Decreased BASK and virtually unchanged CIC content after the use of 0.025 and $0.05 \%$ of prebiotic may indicate a lower level of compensatory reaction of antibody production, aimed at antigen elimination. Thus, use of the studied feed additive could help to reduce effects of stress on fish body in accordance with the spectrum and mechanism of action of the product. It should be noted an increase in PI in all experimental groups compared to Control, with the relative stability of PA, which is a qualitative indicator of cellular immunity. An increase in SLA levels in fish of the experimental groups indicates the mobilization of antibacterial function under the effect of the studied product as well as mobilization of the function of phagocytosis stimulation.

Analysis of the results of hystologic and immune parameters of age $-1+$ carp fed with a feed supplemented with the prebiotic additive during the growing season showed that optimal for further determination of the economic component of cultivation in production conditions are concentrations of 0.025 and $0.05 \%$.

\section{Conflict of interest}

The authors declare that there is no conflict of interest.

\section{References}

Akhter, N., Wu, B., Memon A. M. \& Mohsin M. (2015). Probiotics and prebiotics associated in aquaculture: a review. Fish Shellfish Immunol, 45, 733-741. doi: 10.1016/j.fsi.2015.05.038.

Andrews, S. R., Narottam, P., Sahu, N., Pal, A. K., \& Kumar, S. (2009). Haematological modulation and growth of Labeo rohita fingerlings: effect of dietary mannan oligosaccharide, yeast extract, protein hydrolysate and chlorella. Aguaculture Research, 41(1), 61-69. doi: 10.1111/j.1365-2109.2009.02304.x.

Asaduzzaman, M. D., Iehata, S., Aker, S., Kader, M. D. A., Ghosh, S. K., Nurul Absar Khan, M., \& Abol-Muna, A.B. (2018). Effects of host gut-derived probiotic bacteria on gut morphology, microbiota composition and volatile short chain fatty acids production of Malaysian Mahseer Tor tambroides. Aguaculture Research, 9, 53-61. doi: 10.1016/j.aqrep.2017.12.003.

Avtandilov, H. H. (1990). Meditsinskaia morfometriia. M., Medytsyna (in Russian).

Bondad-Reantaso, M. G., Subasinghe, R. P., \& Arthur, J. R. (2005). Disease and health management in Asian aquaculture. Vet Parasitol, 132(3-4), 249-272. doi: 10.1016/j.vetpar.2005.07.005.

Chernikova, G., \& Procopenko, N. (2017). Slaughter quality of broiler-chickens by prebiotic Actigen using. Agrobiodiversity, 1, 50-53. doi: 10.15414/agrobiodiversity.2017.2585-8246.50-53.

Chernushenko, E. F., \& Kogosova, P. S. (1981). Immunologiya i immunopatologiya zabolevaniy legkikh - Immunology and the dysimmunity of phthisis. Kyiv (in Russian).

Das, S., Mondal, K., \& Haque, S. (2017). A review on application of probiotic, prebiotic and synbiotic for sustainable development of aquaculture. Journal of Entomology and Zoology Studies, 5(2), 422-429. URL: https://www.entomoljournal.com/archives/ 2017/vol5issue2/PartF/5-1-82-948.pdf

Dekhtiarov, P. A., Yevtushenko, M. Yu., Sherman, I. M. (2008). Fiziolohiia ryb. K., Ahrarna osvita (in Ukrainian).

Dimitroglou, A., Merrifield D. L., Moate, R., Davies S. J., Spring, P., Sweetman, J. \& Bradley G. (2009). Dietary mannan oligosaccharide supplementation modulates intestinal microbial ecology and improves gut morphology of rainbow trout, $\mathrm{On}$ corhynchus mykiss (Walbaum). J. Anim. Sci., 87(10), 32263234. doi: $10.2527 /$ jas.2008-1428.

Dobrianska, O. P., Deren, O. V. \& Hryhorenko, T. V. (2019). Produktyvni pokaznyky dvolitok koropa pry zastosuvanni v hodivli prebiotyka v umovakh vyroshchuvalnykh staviv. Rybohospodarska nauka, 4(50), 95-108. doi: 10.15407/fsu2019.04.095 (in Ukrainian).

European Convention for the Protection of Vertebrate Animals Used for Research and Other Scientific Purposes. Strasbourg, March 18, 1986

Grisdale-Helland, B., Helland, S. J. \& Gatlin III D. M. (2008). The effects of dietary supplementation with mannanoligosaccharide, fructooligosaccharide or galactooligosaccharide on the growth and feed utilization of Atlantic salmon. Aquaculture, 283(1-4), 163-167. doi: 10.1016/j.aquaculture.2008.07.012.

Guerreiro, I., Olivia-Teles, A., \& Enes, P. (2018). Prebiotics as functional ingredients: Focus on Mediterranean fish aquaculture. Rev. Aquac., 10, 800-832. doi: 10.1111/RAQ.12201.

Gultepe, N., Salnur, S., Hossu B. \& Hisar, O. (2010). Dietary supplementation with Mannanoligosaccharides (MOS) from Bio-Mos enhances growth parameters and digestive capacity of gilthead sea bream (Sparus aurata). Aquac. Nutr., 17(5), 482487. doi: 10.1111/j.1365-2095.2010.00824.x.

Haievska, M. Iu. (2000). Tsyrkuliuiuchi imunni kompleksy za umov normy tapatolohii. Visn. nauk. dosl., 4, 37-40 (in Ukrainian).

Horalskyi, L. P. (2005). Osnovy histolohichnoi tekhniky i morfofunktsionalni metody doslidzhen u normi ta pry patolohii. Zhytomyr, Polissia (in Ukrainian). 
Hoseinifar, S. H., Cuesta, A., Sun, Y., \& Cuesta, A. (2015). Prebiotics and Fish Immune Response: A Review of Current Knowledge and Future Perspectives. Reviews in Fisheries Science \& Aquaculture. 23(4), 315-328. doi: 10.1080/23308249.2015.1052365.

Ibrahem, M. D., Fathi, M., Mesalhy, S. \& Abd El-Aty, A. M. (2010). Effect of dietary supplementation of Inulin and vitamin $\mathrm{C}$ on the growth, hematology, innate immunity and resistance of Nile tilapia (Oreochromis niloticus). Fish Shellfish Immunol., 29, 241-246. doi: 10.1016/j.fsi.2010.03.004.

Koryliak, M. Z. (2015). Morfolohichna kharakterystyka kyshkivnyka ta hepatopankreasu dvolitok koropa pry zastosuvanni rozmelenykh plodiv roztoropshi pliamystoi. Naukovyi visnyk Lvivskoho natsionalnoho universytetu veterynarnoi medytsyny ta biotekhnolohii imeni S. Z. Gzhytskoho, 17, 218-223 (in Ukrainian).

Kotsiumbas, I. Ya., Zhyla, M. I., Piatnychko, O. M. [ta in.]. (2014). Imunotoksykolohichnyi kontrol veterynarnykh preparativ ta kormovykh dobavok. Metodychni rekomendatsii. Lviv (in Ukrainian).

Maslianko, R. P. (1999). Osnovy imunolohii. Lviv: Vertykal (in Ukrainian).

Merrifield, D., \& Ringo, E. (2014). Aquaculture nutrition. Gut health, probiotics and prebiotics. Chichester, Wiley-Blackwell Publishing.

Mikryakov, V. R. (1991). Zakonomernosti formirovaniya priobretennogo immuniteta u ryib. Ryibinsk: IBVV RAN (in Russian).

Nayak, S. K. (2010). Probiotics and immunity: a fish perspective. Fish Shellfish Immunol., 29(1), 2-14. doi: 10.1016/j.fsi.2010.02.017.

Reverter, M., Bontemps, N., Lecchini, D., Banaigs, B. \& Sasal, P. (2014). Use of plant extracts in fish aquaculture as an alternative to chemotherapy: Current status and future perspectives. Aquacult., 433, 50-61. doi: 10.1016/j.aquaculture.2014.05.048.

Ringo, E., Olsen, R. E., Gifstad, T. O., Dalmo, R. A., Amlung, H., Hemre, G-I., \& Bakke, A. M. (2010). Prebiotics in aquaculture: a review. Aquaculture Nutrition, 16(2), 117-136. doi: 10.1111/j.1365-2095.2009.00731.x.

Robb, D. H. F., \& Crampton, V. O. (2013). On-farm feeding and feed management: perspectives from the fish feed industry. On-farm feeding and feed management in aquaculture. Rome: FAO, 2013. 489-518. (FAO Fisheries and Aquaculture Technical Paper; No. 583).

Rotkiewicz, T. (1990). Patomorfologiczne metody badania zwierzat. ART Olsztyn.

Samrongpan, C., Areechon, N., Yoonpundhan, R., \& Srisapoome, P. (2008). Effects of mannan oligosaccharide on growth survival and disease resistance of Nile Tilapia (Oreochromis niloticus L.) fry. Proceedings of the 8th International Symposium on Tilapia in Aquaculture, October 12-18, 2008, Cairo, Egypt, 345-353.

Sang, H. M., \& Fotedar, R. (2010). Effects of mannan oligosaccharide dietary supplementation on performances of the tropical spiny lobsters juvenile (Panulirus ornatus, Fabricius 1798). Fish Shellfish Immunol., 28(3), 483-489. doi: 10.1016/j.fsi.2009.12.011.

Secomber, C. J. (1996). The nonspecific immune system: cellular defences. The fish immune system. Fish Physiology series, 15, 63-103.

Song, S. K., Beck, B. R., Kim, D., Park, J., Kim, J., Kim, H. D., \& Ringø, E. (2014). Prebiotics as immunostimulants in aquaculture: A review. Fish Shellfish Immunol., 40(1), 40-48. doi: 10.1016/j.fsi.2014.06.016.

Statistical principles for veterinary clinical trials. CVMP/EWP/81976/2010.

Tarasenko, N. A., \& Filippova, E. V. (2014). Briefly on prebiotics: history, classification, preparation, application. Basic research, 6,1 .

Torrecillas, S., Makol, A., Caballero, M. J., Montero, D., Ginés, R., Sweetman, J., \& Izquierdo, M. (2011). Improved feed utilization, intestinal mucus production and immune parameters in sea bass (Dicentrarchus labrax) fed mannan oligosaccharides (MOS). Aquacult Nutr., 17(2), 223-233. doi: 10.1111/j.13652095.2009.00730.x.

Torrecillas, S., Makol, A., Caballero, M. J., Montero, D., Robaina L. et al. (2007). Immune stimulation and improved infection resistance in European sea bass (Dicentrarchus labrax) fed mannan oligosaccharides. Fish Shellfish Immunol., 23(5), 969981. doi: 10.1016/j.fsi.2007.03.007.

Torrecillas, S., Montero, D., \& Izquierdo, M. (2014). Improved health and growth of fish fed mannan oligosaccharides: potential mode of action. Fish Shellfish Immunol., 36(2), 525-544. doi: 10.1016/j.fsi.2013.12.029.

Ye, J., Liu, X., Wang, Z., \& Wang, K. (2011). Effect of partial fish meal replacement by soybean meal on the growth performance and biochemical indices of juvenile Japanese flounder Paralichthys olivaceus. Aquacult Int., 19, 143-153. doi: 10.1007/s10499-010-9348-1.

Zhyla, M. I. (2011). Laboratorni doslidzhennia pry klinichnomu vyprobuvanni veterynarnykh likarskykh zasobiv. Naukovyi visnyk Lvivskoho natsionalnoho universytetu veterynarnoi medytsyny ta biotekhnolohii im. S. Z. Gzhytskoho, 13(4(1), 128-134 (in Ukrainian).

Ziółkowska, E., Bogucka, J., Dankowiakowska, A., Rawski, M., Mazurkiewicz, J., \& Stanek, M. (2020). Effects of a TransGalactooligosaccharide on Biochemical Blood Parameters and Intestine Morphometric Parameters of Common Carp (Cyprinus carpio L.). Animals, 10(4), 723. doi: 10.3390/ani10040723. 